
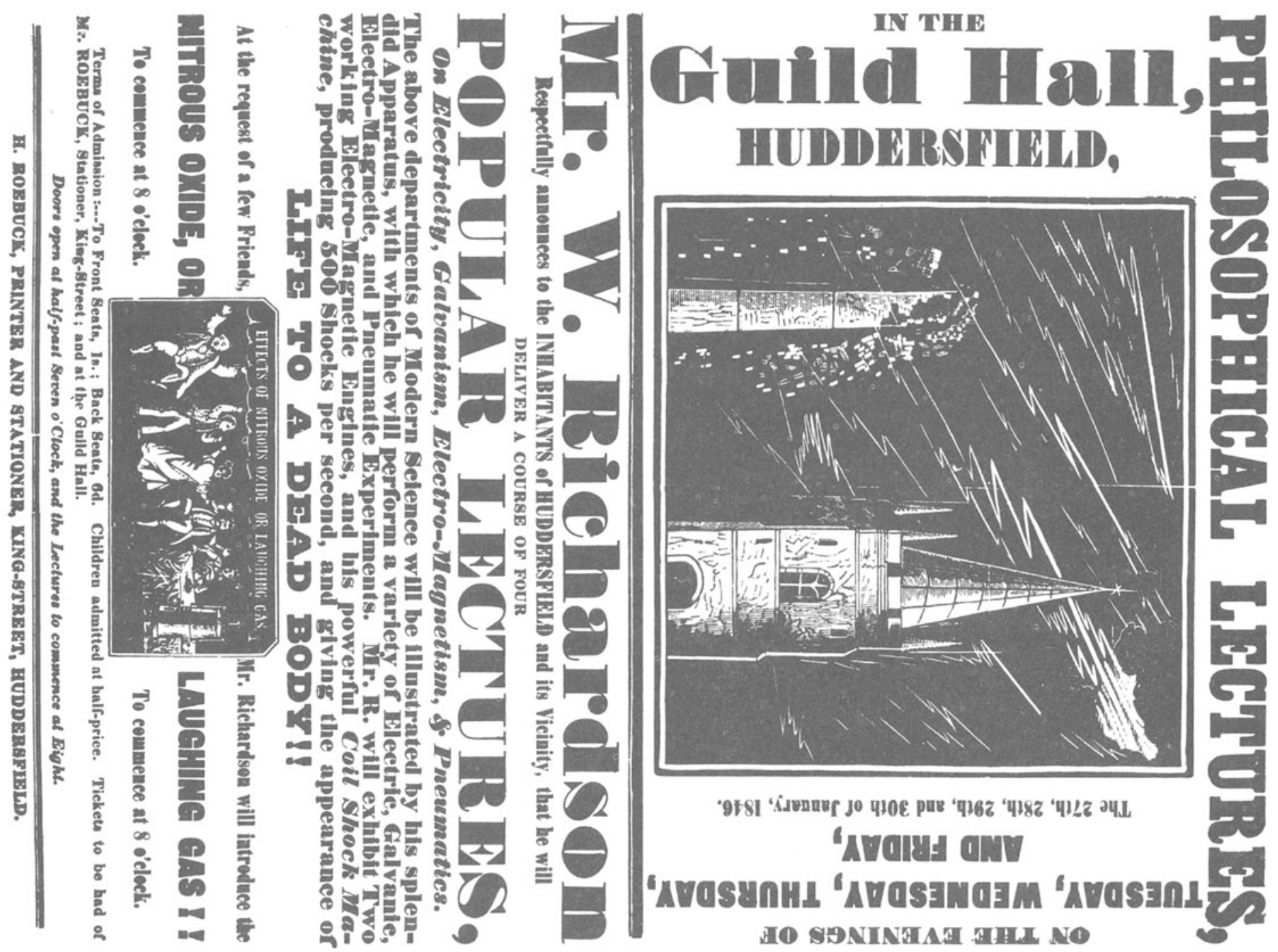
Electrical and Electronic Systems and Practice I 
Macmillan Technician Series

Peter Astley, Engineering, Drawing and Design II

P. J. Avard and J. Cross, Workshop Processes and Materials I

G. D. Bishop, Electrical and Electronic Systems and Practice I

G. D. Bishop, Electronics II

G. D. Bishop, Electronics III

J. C. Cluley, Electrical Drawing I

John Elliott, Building Science and Materials

John G. Ellis and Norman J. Riches, Safety and Laboratory Practice

D. E. Hewitt, Engineering Science II

P. R. Lancaster and D. Mitchell, Mechanical Science III

Rhys Lewis, Physical Science I

Noel M. Morris, Digital Techniques

Noel M. Morris, Electrical Principles II

Noel M. Morris, Electrical Principles III

Owen Perry and Joyce Perry, Mathematics I

A. Simpson, Light Current Electrical Applications III 


\title{
Electrical and Electronic Systems and Practice I
}

\author{
G. D. Bishop \\ Vice Principal, Bridgwater College
}


All rights reserved. No part of this publication may be reproduced or transmitted, in any form or by any means, without permission

First published 1981 by

THE MACMILLAN PRESS LTD

London and Basingstoke

Associated companies in Delhi Dublin

Hong Kong Johannesburg Lagos Melbourne

New York Singapore and Tokyo

ISBN 978-0-333-30454-9 ISBN 978-1-349-05736-8 (eBook)

DOI 10.1007/978-1-349-05736-8

Typset by Oxprint Ltd, Oxford

This book is sold subject to the standard conditions of the Net Book Agreement.

The paperback edition of this book is sold subject to the condition that it shall not, but way of trade or otherwise, be lent, resold, hired out, or otherwise circulated without the publisher's prior consent in any form of binding or cover other than that in which it is published and without a similar condition including this condition being imposed on the subsequent purchaser. 


\section{Contents}

Foreword

\section{Preface}

1 The Electrical and Electronic Industries

1.1 A Short History of the Industries

1.1.1 Electronic developments

Table 1.1 A history of electrical and electronic developments

1.1.2 Changes in manufacturing methods

1.2 A Survey of Present-day Electrical/Electronic Manufacture

1.2.1 Industry categories

1.2.2 The job of the technician

1.2.3 One typical industry

1.3 An Outline of General Industrial Manufacture

Exercises

\section{System Types}

2.1 Definition of a System and its Components, the Blood

Circulation System, the Telephone System, the Electricity

Distribution system

Table 2.1 System types, components, links, aims and examples

2.2 The Nature of Signals

2.3 (Table 2.2) Information systems

2.4 (Table 2.3) Power utilisation systems

2.5 (Table 2.4) Control systems

2.6 (Table 2.5) Amplifier systems

2.7 Modulation and Transmission

2.8 Oscillators

Exercises

3 System Inputs and Outputs

3.1 Transducers

xiii

1

1

2

4

6

7

8

8

9

10

11

12

12

13

16

19

19

19

20

23

25

26

28

28

\author{
Items described \\ Early inventors; a.c. d.c. supply \\ Radio, TV, computers \\ Production methods \\ The structure of industry; the place of the technician \\ Electrical and electronic \\ A firm \\ Product manufacture; the selling price
}

Inputs, outputs, boundaries; the systems approach; block diagrams

d.c., fluctuating d.c.; a.c., pulses, frequency;

Simple a.c. generator, sinewave;

Electromagnetic frequency spectrum;

Feedback loop, a.g. c

Radiation from aerials

Radio telegraphy, modulation, carrier signal, sky waves

Positive feedback, distortion
Thermocouples, thermistors, position transducers, solar cell, photo-diode, light-dependent resistor, strain gauge, piezoelectric crystal, microphone, loudspeaker, gas sensor, radar, ultrasonic detectors 


\subsection{Signal Processing}

3.3 Power Supplies

3.4 Output Devices

\subsection{Cables and Connectors}

Table 3.1 Properties of solid wire

Table 3.2 Properties of stranded power cable

Exercises

\section{Electrical and Electronic Components}

4.1 Electronic Components, Resistors

\subsubsection{Capacitors}

\subsubsection{Inductors}

4.1.3 Other components

4.2 Semiconductor Components

4.3 Logic Gates

4.4 Batteries

4.5 Circuit Symbols

4.6 Electrical Power Components

4.6.1 Conductors and switching

4.6.2 Protection and control
46

46
Amplification and attenuation, amplifiers (summing, d.c., log) modulation, varicap diode, AM, FM filters and tuning, bandwidth coding and decoding, synchronising radio detection, superhets, colour TV Current, voltage supply rectifiers (half-wave full-wave, smoothing) step-down transformer, bridge rectifier regulation, regulated supply

Electromagnetic devices, solenoid relay, bell, door chime, trip, motor, moving-coil meter

Single conductors, stranded conductors, ratings, power cables, screened cables, multicore cable,

Plugs/sockets, soldering, connectors, junction box, conduit, coaxial cables

Resistors (wirewound, carbon, power) ratings, series/parallel connection variable resistor, resistivity Basic calculation, permittivity, electrolytic and other types, reactance series/parallel capacitors Reactance of inductors, chokes, transformers, efficiency, turns ratio series/parallel inductors Fuses, crystals n-type, p-type, diode, transistors, thyristor, triac, l.e.d., liquid crystal, integrated circuits; The systems approach Binary arithmetic, basic gates NOT AND OR NAND NOR, flip-flop

Dry cells, wet cells, Leclanché cell, layer battery, mercury cell, alkaline cell, nickel-cadmium cell, lead-acid accumulator, internal resistance, discharge rates

BS 3939 for electrical and electronic symbols Larger currents, voltages, power, power factor, protection

Distribution boards, bus-bars, screw connectors, joining methods, isolators, arcing suppression

Circuit-breakers, trips, ring mains, metering, the unit and payment 


\subsubsection{Other electrical components}

4.7 Component Reliability

Table 4.3 Component failure rates

Table 4.4 Corrected component failure rates

Exercises

\section{Measurements and Instruments}

5.1 The Types of Signal to be Measured

5.2 Measuring Instruments

5.2.1 Moving-coil and moving-iron instruments

5.2.2 Ammeters, voltmeters and ohm-meters

5.2.3 Multimeters

5.2.4 The resistance bridge

5.2.5 The pen recorder

5.2.6 The oscilloscope

5.3 Taking Measurements

5.3.1 Diodes

5.3.2 Transistors

5.3.3 Capacitors

5.3.4 Inductors and transformers

5.4 Measuring Frequency Responses and Gains

5.5 Instrument Limitations

5.6 Practical Exercises

Exercises
77

78

80

80

82

82

Fluorescent lamps, starters, thermostat, simmerstat, ovenstat, three-phase supplies, motor types (shadedpole, electric clock, universal)

Failure rates of common components, mean time to failure

a.c. and d.c.; low-frequency and high-frequency; resistance

Moving-coil, moving-iron, oscilloscope

Internal resistance, ohms/volt sensitivity

Galvanometers, damping, conversions to voltage and higher current ranges and resistance, shunts, multipliers, multimeters, electronic meters

\section{$X-Y$ plotter}

Scanning, timebase, $Y$ amplifier, setting up and advantages, instrument earthing

Using multimeters, safety precautions

Checking diodes

Checking transistors with an ohm-meter

Use of the oscilloscope, gain calculation, reading frequency and periods, plotting

Frequency responses, estimation of bandwidth, decibel measurements

(1) Regulation

(2) $C-R$ differentiation circuit

(3) $C-R$ integration circuit

(4) Operational amplifier circuits

(5) Operational amplifier circuits to perform (2) and (3) and other functions 


\section{Foreword}

This book is written for one of the many technician courses now being run at technical colleges in accordance with the requirements of the Technician Education Council (TEC). This Council was established in March 1973 as a result of the recommendation of the Government's Haslegrave Committee on Technical Courses and Examinations, which reported in 1969. TEC's functions were to rationalise existing technician courses, including the City and Guilds of London Institute (C.G.L.I.) Technician courses and the Ordinary and Higher National Certificate courses (O.N.C. and H.N.C.), and provide a system of technical education which satisfied the requirements of 'industry' and 'students' but which could be operated economically and efficiently.

Four qualifications are awarded by TEC, namely the Certificate, Higher Certificate, Diploma and Higher Diploma. The Certificate award is comparable with the O.N.C. or with the third year of the C.G.L.I. Technician course, whereas the Higher Certificate is comparable with the H.N.C. or the C.G.L.I. Part III Certificate. The Diploma is comparable with the O.N.D. in Engineering or Technology, the Higher Diploma with the H.N.D. Students study on a part-time or block-release basis for the Certificate and Higher Certificate, whereas the Diploma courses are intended for full-time study. Evening study is possible but not recommended by TEC. The Certificate course consists of fifteen Units and is intended to be studied over a period of three years by students, mainly straight from school, who have three or more C.S.E. Grade III passes or equivalent in appropriate subjects such as mathematics, English and science. The Higher Certificate course consists of a further ten Units, for two years of part-time study, the total time allocation being 900 hours of study for the Certificate and 600 hours for the Higher Certificate. The Diploma requires about 2000 hours of study over two years, the Higher Diploma a further 1500 hours of study for a further two years.

Each student is entered on to a Programme of study on entry to the course; this programme leads to the award of a Technician Certificate, the title of which reflects the area of engineering or science chosen by the student, such as the Telecommunications Certificate or the Mechanical Engineering Certificate. TEC have created three main Sectors of responsibility: 
Sector A responsible for General, Electrical and Mechanical Engineering

Sector B responsible for Building, Mining and Construction Engineering

Sector $\mathrm{C}$ responsible for the Sciences, Agriculture, Catering, Graphics and Textiles.

Each Sector is divided into Programme committees, which are responsible for the specialist subjects or programmes, such as A1 for General Engineering, A2 for Electronics and Telecommunications Engineering, A3 for Electrical Engineering, etc. Colleges have considerable control over the content of their intended programmes, since they can choose the Units for their programmes to suit the requirements of local industry, college resources or student needs. These Units can be written entirely by the college, thereafter called a college-devised Unit, or can be supplied as a Standard Unit by one of the Programme committees of TEC. Assessment of every Unit is carried out by the college and a pass in one Unit depends on the attainment gained by the student in his coursework, laboratory work and an end-ofUnit test. TEC moderate college assessment plans and their validation; external assessment by TEC will be introduced at a later stage.

The three-year Certificate course consists of fifteen Units at three Levels: I, II and III, with five Units normally studied per year. A typical programme might be as follows.

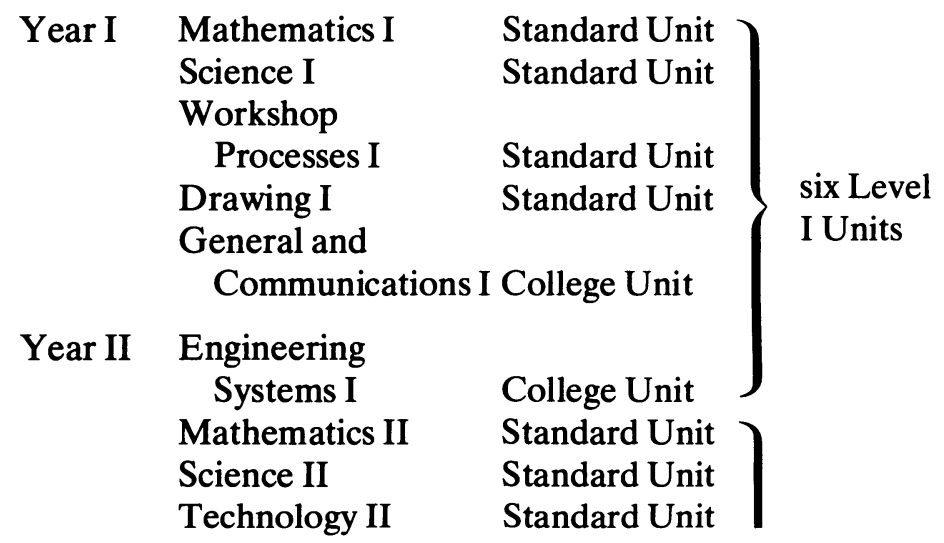

$\left.\begin{array}{ll|l}\begin{array}{l}\text { General and } \\ \text { Communications }\end{array} & \\ \text { II } & \text { College Unit } \\ \text { Industrial } & & \text { six Level } \\ \text { II Units } \\ \begin{array}{c}\text { Studies II } \\ \text { Engineering }\end{array} & \text { College Unit } & \\ \begin{array}{l}\text { Systems II } \\ \text { Mathematics }\end{array} & \text { College Unit } \\ \text { III } & \text { Standard Unit } \\ \text { Science III } & \begin{array}{l}\text { Standard Unit } \\ \text { Technology III }\end{array} & \text { College Unit }\end{array}\right\}$

Entry to each Level I or Level II Unit will carry a prerequisite qualification such as C.S.E. Grade III for Level I or O-level for Level II: certain Craft qualifications will allow students to enter Level II direct, one or two Level I Units being studied as 'trailing' Units in the first year. The study of five Units in one college year results in the allocation of about two hours per week per Unit, and since more subjects are often to be studied than for the comparable City and Guilds course, the treatment of many subjects is more general, with greater emphasis on an understanding of subject topics rather than their application. Every syllabus to every Unit is far more detailed than the comparable O.N.C. or C.G.L.I. syllabus, presentation in Learning Objective form being requested by TEC. For this reason a syllabus, such as that followed by this book, might at first seem very long, but analysis of the syllabus will show that 'in-depth' treatment is not necessary-objectives such as 'states Ohm's law' or 'lists the different types of telephone receiver' clearly do not require an understanding of the derivation of the Ohm's law equation or the operation of several telephone receivers.

This book satisfies the learning objectives for one of the many TEC Standard Units, as adopted by many technical colleges for inclusion into their Technician programmes. The treatment of each topic is carried to the depth suggested by TEC, and in a similar way the length of the Unit (sixty hours of study for a full Unit), prerequisite qualifications, credits for alternative qualifications and aims of the Unit have been taken into account by the author. 


\section{Preface}

This book is written for all students following Technician Education Council (TEC) programmes in Electronics Engineering (A2), Electrical Engineering (A3) and Radio and Television Engineering (A2) at certificate and diploma level. It covers the syllabus content of the level I systems content of each programme, written in 'suggested guidelines' form and entitled Electronic systems and practice I or

Electrical and electronic systems I.

The content of these units is listed as follows

Electronic systems and practice I

the electronics industry

electronic systems and signals

transducers, sources, amplifiers

circuits and components

interconnections, power supplies

Electrical and Electronic systems I

power utilisation systems

information systems

control systems

a.c./d.c. generators

a.c. apparatus and switching

instrumentation

There are no stated prerequisite qualifications for entry to these units and the standard of mathematics is low. It is assumed, however, that other level I units are being studied in conjunction with the content of this book, namely Mathematics and Physical Science I. After completing this book, the reader will be able to proceed to level II units in Electronics, Electrical Principles and Applications of Radio and Television subjects.

A broad approach to systems technology is given throughout the book and many non-technical systems are mentioned or described. The systems approach can be adapted to any system: modern electrical and electronic equipment is often of a modular construction which lends itself to system-type servicing and maintenance. The book starts with a short history of the industry and the gradual development of electrical component technology. The role of the technician in present-day industry is discussed and the structure of typical small and large industries. Chapter 2 describes several systems, their input and output 
signals and their links and aims. Any system has at its input and output a transducer or generator, or other device, interconnected by cables appropriate to the signals being transmitted. Chapter 3 describes these devices and the signal processing that takes place in electrical circuits. The black box is then opened up in chapter 4, which describes all the various system components, including batteries and electrical power components; there is also a section on component reliability. Finally, chapter 5 discusses measuring instruments and the ways of using them.

Exercises are given at the end of each chapter, with full answers at the end of the book. Since this unit is mainly descriptive, the majority of the questions are of the short-answer type; the reader is encouraged to work through every question and check the answer when completed. A total of 96 questions is included, together with several practical exercises in chapter 5, where the reader is expected to apply some systems technology to some simple measurements exercises.

G. D. Bishop 